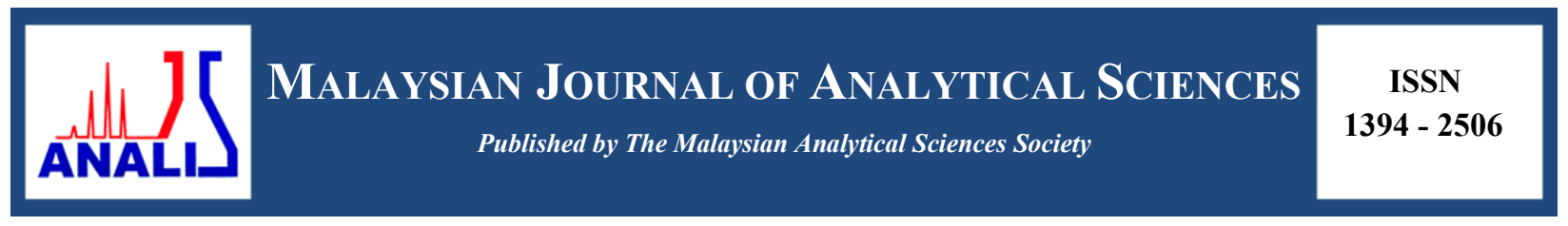

\title{
COMPARISON STUDY BETWEEN EXTRUSION AND INJECTION MOLDING ON CELLULAR STRUCTURE OF PP/PS/PMMA TERNARY BLEND FOAM
}

\section{(Kajian Perbandingan di antara Kaedah Proses Penyemperitan dan Proses Pengacuan Suntikan ke atas Struktur Sel PP/PS/PMMA Campuran Pertigaan Busar Polimer)}

\author{
Rahida Wati Sharudin ${ }^{1,3 *}$ and Masahiro Ohshima ${ }^{2}$ \\ ${ }^{I}$ Faculty of Chemical Engineering, \\ Universiti Teknologi MARA, 40450 Shah Alam, Selangor, Malaysia \\ ${ }^{2}$ Department of Chemical Engineering, \\ Kyoto University, Kyoto 615-8510, Japan \\ ${ }^{3}$ Institute for Infrastructure Engineering \& Sustainable Management (IIESM), Faculty of Civil Engineering, \\ Universiti Teknologi MARA, 40450 Shah Alam, Malaysia
}

*Corresponding author: rahida@salam.uitm.edu.my

Received: 21 October 2015; Accepted: 14 June 2016

\begin{abstract}
The effect of blending method on the blend morphology as well as cellular structure of Polypropylene (PP)/Polystyrene (PS)/ Polymethyl methacrylate (PMMA) ternary polymer blend was investigated. The blending method highly influenced the dispersion and size of dispersed domain where the injection molding method was successfully reduced the size of dispersed domain from $10 \mu \mathrm{m}$ by extrusion further down to $1 \mu \mathrm{m}$ in average diameter. The batch pressure quenched foaming of the ternary blend prepared by extrusion and injection molding with supercritical carbon dioxide $\left(\mathrm{CO}_{2}\right)$ was conducted in the temperature range of 130 to $160^{\circ} \mathrm{C}$ to observe the controllability of bubble location and size in two different ternary blend systems. The experimental results showed that method of sample preparation is one of the important factors in controlling the cellular structure of ternary blend foam besides interfacial tension, foaming temperature, and viscoelasticity.
\end{abstract}

Keywords: polymer blend, extrusion, injection molding, cellular structure, foam

\section{Abstrak}

Kesan kaedah pencampuran pada morfologi dan juga struktur sel Polipropena (PP)/Polisterina (PS)/ Polimetil metaakrilat (PMMA) campuran pertigaan polimer telah dikaji. Kaedah pencampuran sangat mempengaruhi penyebaran dan saiz domain di mana kaedah pengacuan suntikan telah berjaya mengurangkan saiz domain dari $10 \mu \mathrm{m}$ oleh kaedah penyemperitan kepada serendah $1 \mu \mathrm{m}$ diameter purata. Proses pelepasan tekanan secara mendadak dengan karbon dioksida genting lampau $\left(\mathrm{CO}_{2}\right)$ telah dijalankan bagi penghasilan sampel busar daripada gabungan pertigaan polimer dalam lingkungan suhu $60-130^{\circ} \mathrm{C}$ untuk melihat kebolehkawalan lokasi gelembung dan saiz. Keputusan eksperimen menunjukkan bahawa kaedah penyediaan sampel, tegangan antara permukaan dua polimer, suhu pembentukan busar dan likat-kenyal adalah faktor penting untuk mengawal struktur sel dalam sistem gabungan pertigaan polimer.

Kata kunci: percampuran polimer, penyemperitan, pengacuan suntikan, struktur sel, busar 


\section{Introduction}

Polymer blends received many attentions due to the increasing application of plastic industry especially in automobile, packing, and many potential applications. Recently, much attention has been directed to ternary polymer blend [1]. Prior to develop a new material based on multi-component polymer, understanding and controlling the phase morphology are the primary interest. This is because the morphology is directly influenced the mechanical performance in polymer blend [2]. These final properties of polymer blend can be controlled by considering polymer molecular structure, composition, molecular weight [3], and method of blend preparation [4]. According to Guo et al. [5], in ternary polymer system, one of the minor components formed an encapsulating layer around domains of other minor components (encapsulation-type morphology) as shown in Figure 1. Whereas in other systems the two minor components formed independent phases (separation-type morphology).

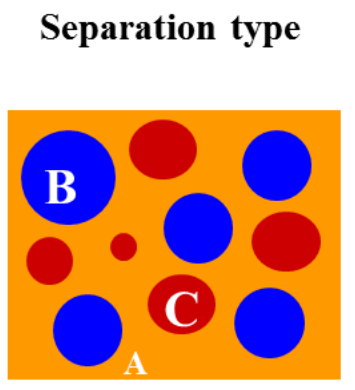

$B$ and $C$ are separated

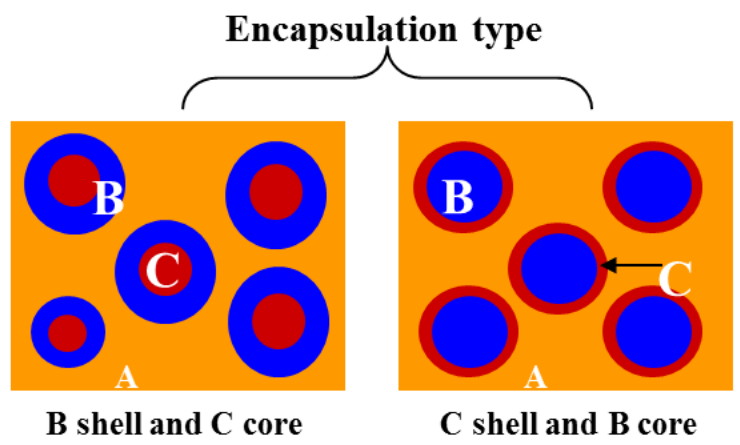

Figure 1. Three possible morphologies of ternary polymer blend, (A: matrix, B and C: dispersed phase)

They claimed that these ternary blend systems can also be predicted by calculating the Gibbs free energy or interfacial energy shown in the following equations [5]:

$$
\begin{aligned}
& \left(\sum A_{i} \gamma_{i j}\right)_{B+C}=(4 \pi)^{1 / 3}\left[n_{B}^{1 / 3} x^{2 / 3} \gamma_{A B}+n_{C}^{1 / 3} \gamma_{A C}\right]\left(3 V_{C}\right)^{2 / 3} \\
& \left(\sum A_{i} \gamma_{i j}\right)_{B / C}=(4 \pi)^{1 / 3}\left[n_{B}^{1 / 3}(1+x)^{2 / 3} \gamma_{A B}+n_{C}^{1 / 3} \gamma_{B C}\right]\left(3 V_{C}\right)^{2 / 3} \\
& \left(\sum A_{i} \gamma_{i j}\right)_{C / B}=(4 \pi)^{1 / 3}\left[n_{B}^{1 / 3} x^{2 / 3} \gamma_{B C}+n_{C}^{1 / 3}(1+x)^{2 / 3} \gamma_{A C}\right]\left(3 V_{C}\right)^{2 / 3}
\end{aligned}
$$

where $A$ is interfacial area, $\gamma_{i j}$ is interfacial tension between component $i$ and $j, V$ is the volume of particle and $x=\mathrm{V}_{\mathrm{B}} / \mathrm{V}_{\mathrm{C}}, n_{B}$ and $n_{C}$ are numbers of particles of $\mathrm{B}$ and $\mathrm{C}$ phases in the system. The values of $\Sigma A \gamma_{i j}$ are compared for the three structures and the equilibrium phase structure of the system is predicted by considering the lowest free energy needed for creating the morphology.

In recent years, there are relatively few studies done on multicomponent blend foaming have been reported. In spite of the fact that the understanding on phase morphology of multicomponent blend is less understood, lack attention is given to ternary polymer blend foaming study. As in binary polymer blend foaming, the concept of creating a microcellular/ nanocellular foam based on solubility and diffusivity of $\mathrm{CO}_{2}$ is also can be applied in ternary polymer blend foaming. By exploiting ternary polymer blend morphology as a template for foaming and by differentiating the solubility of foaming agent as well as the elasticity of the domain to be foamed from the domains to be kept solid state, the bubble location and size could be controlled in the targeting domains [6] as illustrated in Figure 2.

However, the cellular structure is determined not only by the morphology and physical properties of polymers such as viscosity, solubility and diffusivity of the physical foaming agent in the polymers, but also by the size of dispersed domain. Several studies showed that size of dispersed domain was successfully reduced by improving compatibility between polymers [7-10], adding third immiscible component to binary polymer blend [11] and preparing blend sample via injection molding [12]. 
The work described here is a follow-up to our previous study on PP/PS/PMMA ternary blend foaming [6]. In the current study, the effect of dispersed domain's size on cellular structure of ternary polymer blend was investigated. We compare the cellular structure of PP/PS/PMMA blend foams prepared by two different blending methods namely extrusion and injection molding. A series of pressure quench foaming experiments have been conducted to evaluate the role of blending method effects on size of dispersed domain and foaming behaviour of ternary polymer blend.

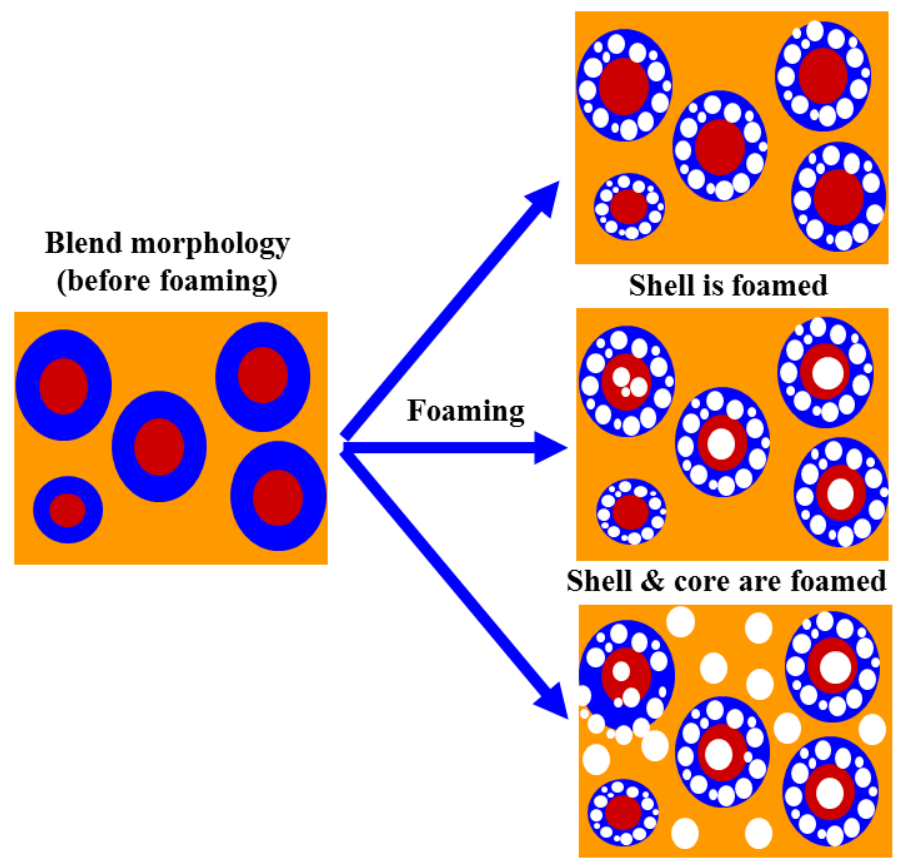

Figure 2. Possible cellular structures of ternary polymer blend foam

\section{Materials}

Polypropylene $(\mathrm{PP}, \mathrm{Mw}=410,000)$ and Polycarbonate $(\mathrm{PC}, \mathrm{Mw}=22,000)$ were supplied by Mitsubishi Chemical. Polystyrene (PS, Mw= 192,000) and Poly (methyl-methacrylate) (PMMA, Mw= 120,000) were obtained from Aldrich Chemical Co. All polymers were used as received.

\section{Sample preparation}

Blend samples were mixed and compounded via injection molding at $260{ }^{\circ} \mathrm{C}$ for PP/PS/PMMA $(80 / 10 / 10)$ and 280 ${ }^{\circ} \mathrm{C}$ for PC/PS/PMMA (80/10/10) blend samples. The morphology of the sheet was investigated via SEM (TinySEM, Technex Lab Co. LTD., Tokyo, Japan).

\section{Batch physical foaming process}

The injection molded PP/PS/PMMA ternary blend samples were placed in a high-pressure vessel. The pressure vessel was pressurized by $\mathrm{CO}_{2}$ and was rapidly heated to the desired saturation temperature. After a given time of saturation (about 6 hours), the $\mathrm{CO}_{2}$ in the pressure vessel was quickly released at a rate of $10 \mathrm{MPa} / \mathrm{s}$ to nucleate bubble in the polymer. The foamed blends were taken out for further analyses mainly by SEM. 


\section{SEM analysis}

Blend as well as foam samples were cryo-fractured by nitrogen gas and were then gold coated prior been analyzed via SEM (Tiny- SEM, Technex Co. Ltd., Japan).

\section{Blend morphology characterization}

\section{Results and Discussion}

In our previous study [6], the SEM micrographs of the obtained PP/PS/PMMA blends before acid acetic and cyclohexane treatments clearly showed the sea and island morphology where PP as a sea while PS/PMMA minor phases existed in the form of a dispersed spherical particles at approximately $10 \mu \mathrm{m}$ in average diameter. It was also observed that some particles were detached while preparing the sample for microscopy analysis, and this resulted in voids in the matrix. According to Reignier et. al [13], there are three possible phase structures could be obtained for ternary blend system which are:

(i) the PMMA phase is encapsulated by the PS phase (PS/PMMA);

(ii) the PS phase is encapsulated by the PMMA phase (PMMA/PS); and

(iii) the PS and PMMA phases form separate phases (PS+PMMA).

For the purpose of identifying type of morphology in PP/PS/PMMA blend, the solvent etching was conducted. It was found that PMMA is encapsulated by PS where PMMA was selectively removed by acetic acid and PS by cyclohexane. The predicted morphologies by interfacial free energy model corroborated the morphologies experimentally as shown in Table 1 . The most stable morphology is represented by the lowest value of surface energy of Gibbs energy of mixing [14].

Figure 3 shows the SEM micrographs of blend morphologies of the samples before and after solvent etching prepared by injection molding. The SEM results show that injection molded of PP/PS/PMMA blend gave elongated domain. The increasing shear flow gave increasing elongation until it reached a critical shear rate at which elongated domains dispersed into finer domain. Our results also show that injection molding was successfully reduced the size of dispersed domain while the morphology remained the same. This indicates that sample with a large number of finely dispersed domain could be achieved by injection molding. According to Zhong et al. [15], smaller dispersed domain can be achieved due to large force acting on the dispersed domains induced by high injection flow rate causes the particles became more deformed and were easier to break up.

Table 1. Predicted equilibrium morphology for PP/PS/PMMA ternary blends by Gibbs free energy or interfacial free energy

\begin{tabular}{lc}
\hline Type of morphology & $\boldsymbol{\Sigma} \mathbf{A} \boldsymbol{\gamma}_{\mathbf{i j}}(\mathbf{d y n e} \mathbf{c m})$ \\
\hline $\mathrm{B}+\mathrm{C}$ & $40.1 \mathrm{~N}$ \\
$\mathrm{~B} / \mathrm{C}$ & $32.6 \mathrm{~N}$ \\
$\mathrm{C} / \mathrm{B}$ & $42.0 \mathrm{~N}$ \\
\hline
\end{tabular}

PP matrix (PP: A, PS: B, PMMA: C)

\footnotetext{
Foaming behavior of PP/PS/PMMA (80/10/10) ternary blend system prepared by extruder and injection molding

In our previous paper [6], we have reported that the pressure quench foaming result demonstrated an interesting phenomenon where a unique cell structure of PS/PMMA dispersed domain was kept their spherical shape and been encapsulated by large void space at foaming temperature range of 130 to $155^{\circ} \mathrm{C}$. From the observation, we claimed that large bubbles were originated from the interface between PP matrix and PMMA/PS core-shell domain, and small bubbles were from PP matrix. For all foaming temperature studied, it was observed that controllability of bubble nucleation and location in PP/PS/PMMA blend was restricted by high interfacial tension between PP matrix
} 
and PMMA/PS core-shell domain. High value of the interfacial tension between two polymers generally provides a channel for $\mathrm{CO}_{2}$ diffusion. As a result, the nucleation of bubble is limited only in amorphous PP matrix and at the interface between PP matrix and PMMA/PS core-shell domain.

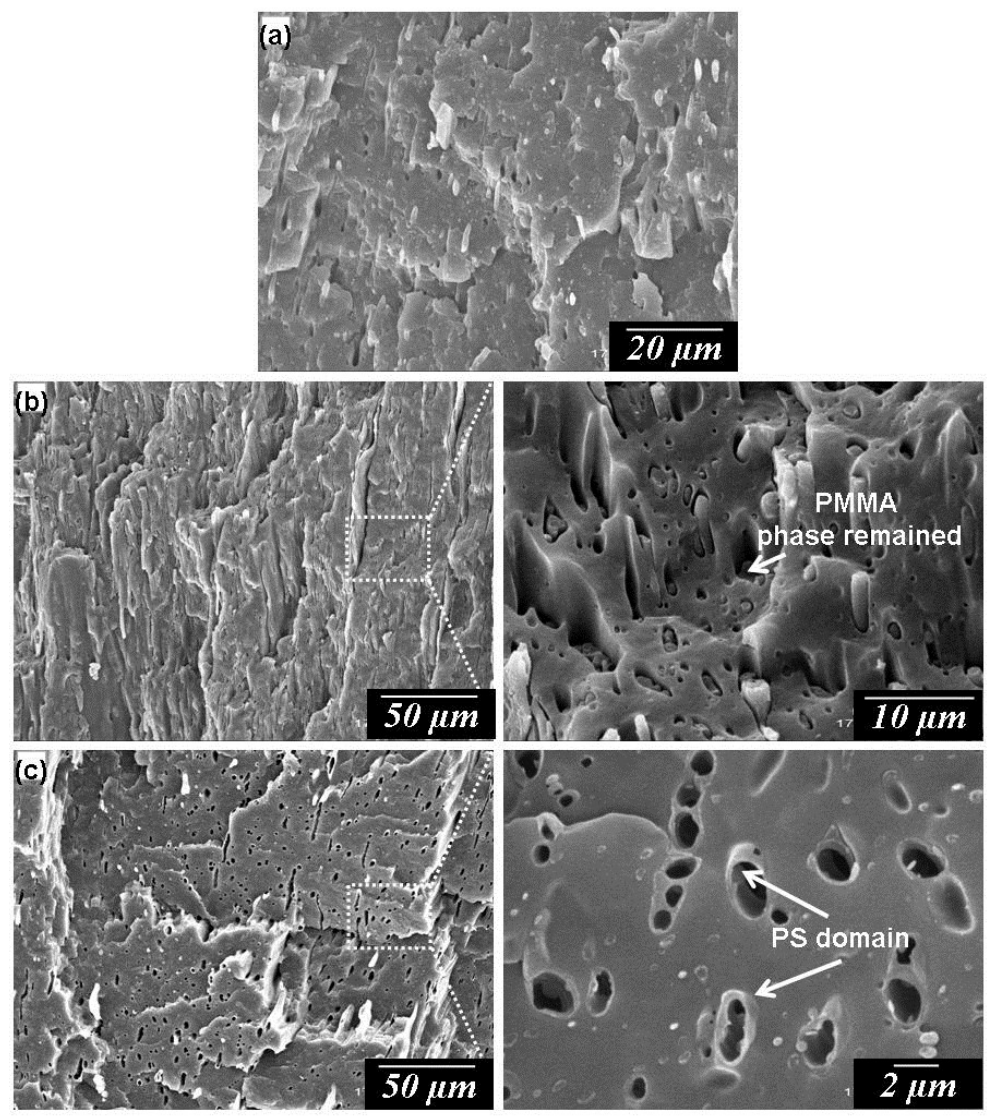

Figure 3. PP/PS/PMMA (80/10/10) ternary blend prepared by injection molding. (a) As-prepared; (b) After cyclohexane etching; and (c) After acetic acid etching.

By using the same concept of preparing microcellular/nanocellular foam as in our previous study, new approach is introduced in order to control the bubble nucleation at polymer interface. It is believed that smaller size of dispersed domain probably could reduce the loss of $\mathrm{CO}_{2}$ via diffusion, and thus enhances bubble nucleation. We use the approach of preparing blend sample via injection molding to obtain smaller dispersed domain as compared to extruded blend sample. As reported by Son et al. [12] injection condition affects domain size where high injection flow rate and low injection temperature could successfully reduce the domain size of dispersed phase.

The observed encapsulation-type morphology of PP/PS/PMMA (80/10/10) blend was utilized as template for foaming. Batch foaming was then performed on the injection molded sample in the temperature range of 130 to 160 ${ }^{\circ} \mathrm{C}$ while the saturation pressure and depressurization rate were kept constant. Figure 4 shows the cell structure of the blend sample corresponding to the SEM image shown in Figure 3. At $130^{\circ} \mathrm{C}$ sample was partly foamed. From the observation, the bubble was originated from amorphous PP while PMMA/PS domains remained as particles. At $150{ }^{\circ} \mathrm{C}$, fine well-distributed cell was obtained. An increased of domain distribution as well as the decreased of average domain size leads to a small cell size and high cell density. Figure $4 \mathrm{c}$ clearly shown the PMMA/PS domains 
were adhered to the PP cell wall. Overall, blend sample prepared by injection molding which has smaller domain size leads to a cell size decrease and cell density increase.
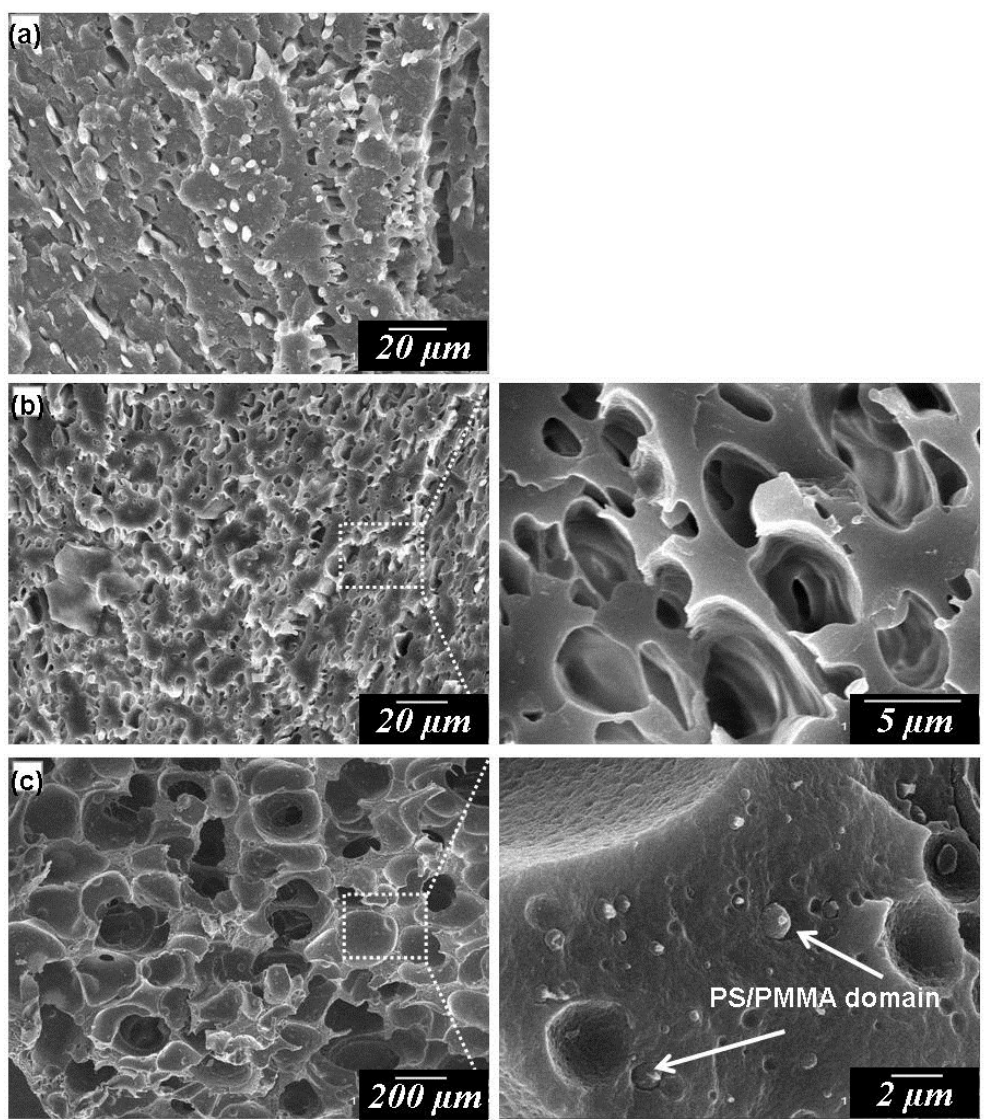

Figure 4. Cell structures of PP/PS/PMMA (80/10/10) foams prepared by injection molding at various foaming temperatures: (a) $130{ }^{\circ} \mathrm{C}$; (b) $150{ }^{\circ} \mathrm{C}$; and (c) $160{ }^{\circ} \mathrm{C}$

Figure 5 compares the graphs of the cell size distribution of PP/PS/PMMA (80/10/10) blend foams prepared by different methods; extrusion and injection molding. The uniformity of cell size was increased in sample prepared by injection molding. The cell size of the extrusion blend foam shows a broad distribution with cell size in a range of 4 to $45 \mu \mathrm{m}$. On the other hand, the cell size distribution of the injection molding blend foam becomes narrower than that of extrusion blend foam, and they are in range from 1 to $12 \mu \mathrm{m}$. Reducing size of dispersed domain showed a beneficial effect on the cellular structure of the investigated blend in terms of cell size and cell uniformity.

Blend morphology and foaming behaviour of PC/PS/PMMA (80/10/10) ternary blend system prepared by injection molding

PC/PS/PMMA (80/10/10) blend was prepared via injection molding to further investigate the effect of dispersed domain size on the cell structure. Blend morphology of sample was first examined to identify the type of morphology. Droplet-type morphology or so called sea-island morphology with nano-sized PS core and PMMA shell was obtained due to incompatibility between those polymers as depicted in Figure 6. 


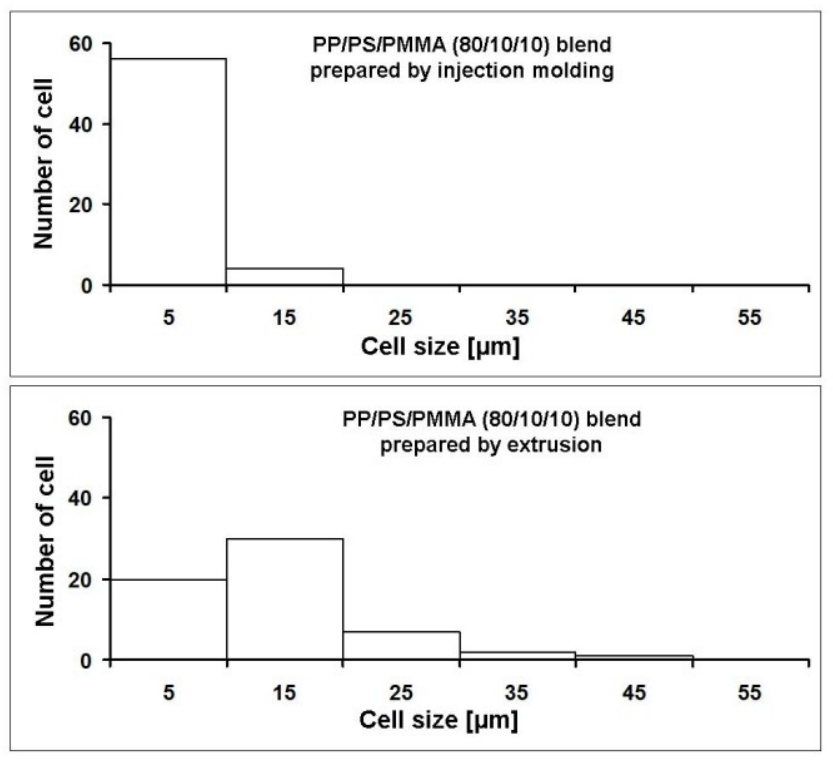

Figure 5. Cell size distribution of PP/PS/PMMA (80/10/10) blend foams at $150{ }^{\circ} \mathrm{C}$
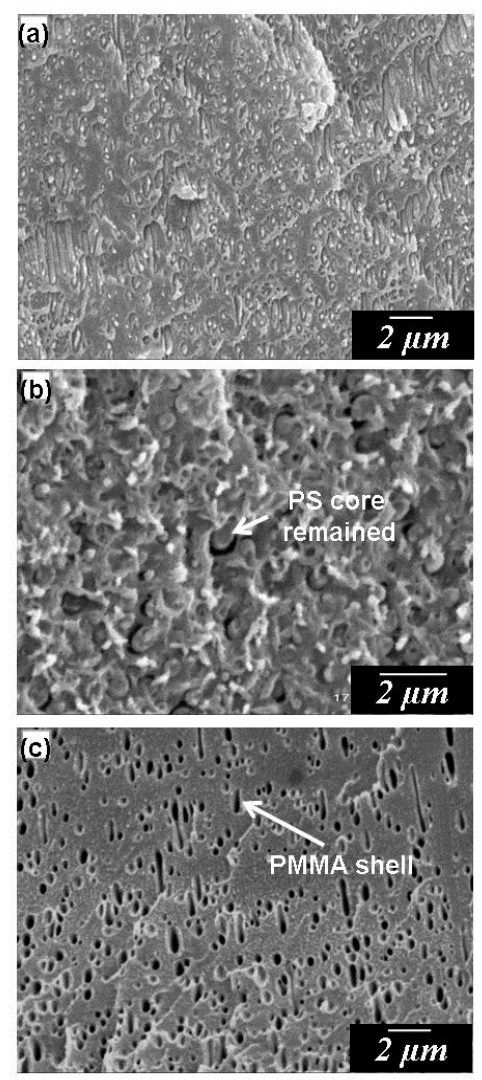

Figure 6. PC/PS/PMMA (80/10/10) ternary blend prepared by injection molding. (a) As-prepared; (b) After acetic acid etching; and (c) After cyclohexane etching 
Under similar foaming conditions, PC/PS/PMMA blend foam was prepared. Figure 7a shows that sample could be foamed slightly at $130{ }^{\circ} \mathrm{C}$. As the foaming temperature increased to $150{ }^{\circ} \mathrm{C}$, bimodal cell structure was formed (Figure 7b). Enlarge image of Figure $7 \mathrm{~b}$ shows that PS/PMMA domain remained as its original shape. When the blend sample was foamed at $160{ }^{\circ} \mathrm{C}$, the foam exhibited a small cell size and low cell density. This might due to the increase in $\mathrm{CO}_{2}$ diffusivity with the increase of the foaming temperature. By comparison of cell structures of PP/PS/PMMA (80/10/10) blend samples prepared by extrusion and injection molding, it can be observed that the decreased in dispersed domain size is not only decreased the cell size, but it also reduced the $\mathrm{CO}_{2}$ diffusion into the polymer interface. Hence, the cell properties of ternary polymer blend could be improved by preparing the sample via injection molding.
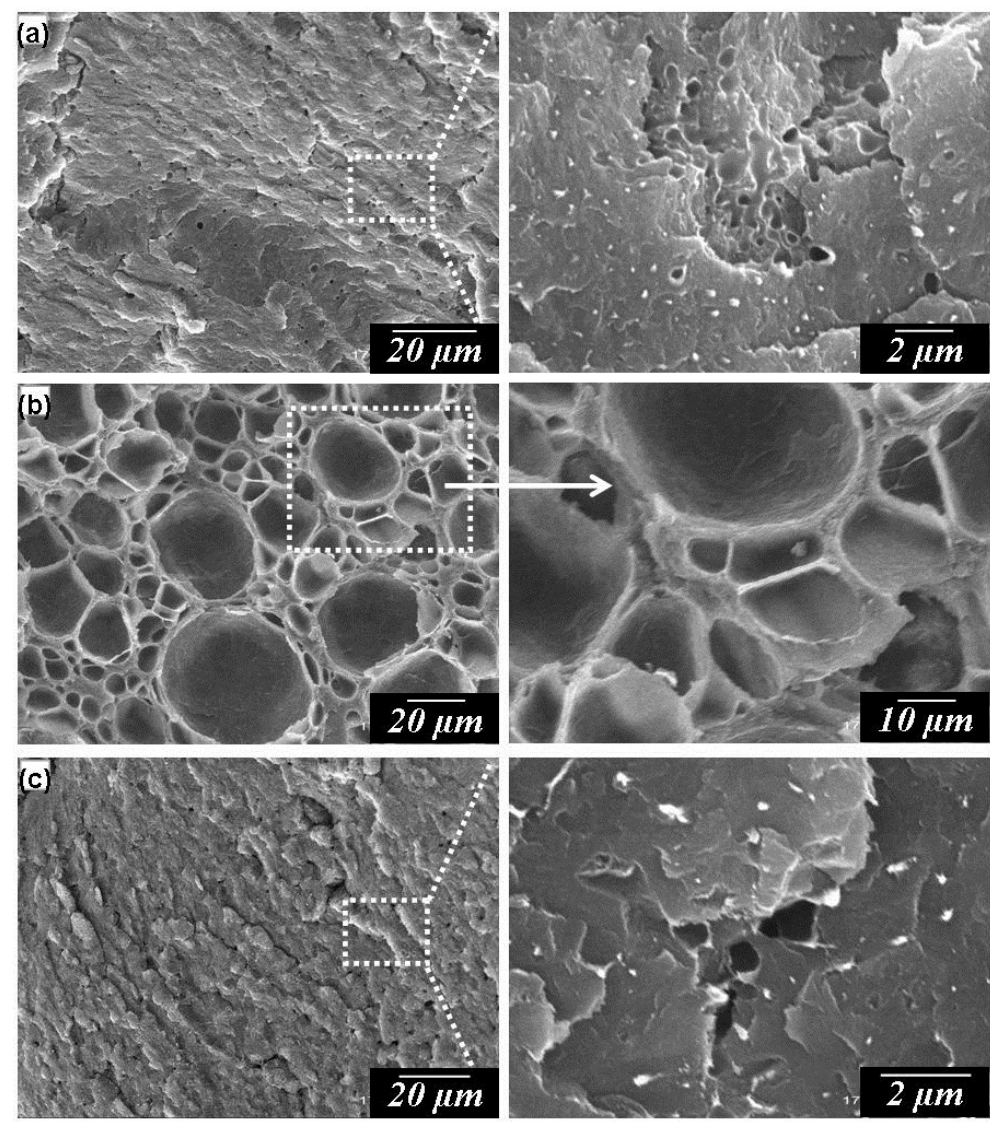

Figure 7. Cell structures of PC/PS/PMMA (80/10/10) foams prepared by injection molding at various foaming temperatures (a) $130{ }^{\circ} \mathrm{C}$, (b) $150{ }^{\circ} \mathrm{C}$ and (c) $160{ }^{\circ} \mathrm{C}$

\section{Conclusion}

The effect of blending method on the dispersed domain size and cellular structure of ternary blend was studied. The approach of preparing blend sample via injection molding has been introduced to control the dispersed domain size of the polymer blend. For the injection molded PP/PS/PMMA blend, an incredible drop of dispersed domain size was observed compared to extruded PP/PS/PMMA blend from approximately $10 \mu \mathrm{m}$ in average diameter to almost $1 \mu \mathrm{m}$. Accordingly, reducing dispersed domain size was found beneficial effect on the cellular structure of the blend. Cell density and uniformity of PP/PS/PMMA blend can be enhanced with the reduction of dispersed domain size, which impedes $\mathrm{CO}_{2}$ loss via diffusion through polymer interface. 


\section{Acknowledgement}

The authors would like to thank the Research Management Institute (RMI), Universiti Teknologi MARA (UiTM) for the financial support of the project under the Research Acculturation Grant Scheme (RAGS) (600RMI/RAGS5/3 (68/2013)). In addition, Material Processing Engineering Laboratory of Kyoto University is also acknowledged for providing material and technical support.

\section{References}

1. Hsu, W.P. (2007). A closed-loop behavior of ternary polymer blends composed of three miscible binaries. Thermochimica Acta, 454: 50 - 56.

2. Tseng, F. P., Lin, J. J., Tseng, C. R. and Chang, F. C. (2001). Poly(oxypropylene)-amide grafted polypropylene as novel compatibilizer for PP and PA6 blends. Polymer, 42: 713 - 725.

3. Radusch, H. J., Dosher, P. and Lause, G. (2005). Phase behaviour and mechanical properties of heterophasic polypropylene-ethylene/ propylene copolymers systems. Polymer, 50: $279-285$.

4. Li, X., Han, Y. and An, L. (2003). Surface morphology control of immiscible polymer-blend thin films. Polymer, 44: 8155 - 8165.

5. Guo, H. F., Packirisamy, S., Gvozdic, N. V. and Meier D. J. (1997). Prediction and manipulation of the phase morphologies of multiphase polymer blends: 1. Ternary systems. Polymer, 38: 785 - 794.

6. Sharudin, R.W., Alwi, H. and Ohshima, M. (2013). PP/PS/PMMA ternary blend foaming using supercritical $\mathrm{co}_{2}$. Advanced Materials Research, 701: $17-22$.

7. Gnatowski, A. and Koszkul, J. (2005). Investigations of the influence of compatibilizer and filler type on the properties of chosen polymer blends. Journal of Materials Processing Technology, 162 - 163: 52 - 58.

8. Kim, J. K., Yi, D. K., Jeon, H. K. and Park, C. E. (1999). Effect of the functional group inhomogeneity of an in situ reactive compatibilizer on the morphology and rheological properties of immiscible polymer blends. Polymer, 40: 2737 - 2743.

9. Zhai, W., Wang, H., Yu, J., Dong, J. and He, J. (2008). Foaming behaviour of polypropylene/ polystyrene blends enhanced by improved interfacial compatibility. Journal of Polymer Science Part B: Polymer Physics, 4 6: $1641-1651$.

10. Zhang, Q., Yang, H. and Fu, Q. (2004). Compatibilization of immiscible poly(propylene)/polystyrene blends using clay. Polymer, $45: 1913-1922$.

11. Elias, L., Fenouillot, F., Majeste, J. C. and Cassagnau, P. H. (2007). Morphology and rheology of immiscible polymer blends filled with silica nanoparticles. Polymer, 48: 6029-6040.

12. Son, Y., Ahn, K. H. and Char, K. (2011). Effects of processing conditions and reactive compatibilizers on the morphology of injection molded poly(phenylene oxide)/Nylon 6 Blends. Polymer Engineering and Sciences, 40 : $1385-1394$.

13. Reignier, J., Favis, B. D. and Heuzey, M-C. (2003). Factors influencing encapsulation behavior in composite droplet-type polymer blends. Polymer, 44(1): $49-59$.

14. Valera, T. S., Morita, A. T. and Demarquette, N. R. (2006). Study of morphologies of PMMA/PP/PS ternary blends. Macromolecules, 39(7): 2663 - 2675.

15. Zhong, G. J. and Li, Z. M. (2005). Injection molding-induced morphology of thermoplastic polymer blends. Polymer Engineering and Sciences, 45(12): 1655 - 1665. 